\title{
The Pharmacokinetic Drug-Drug Interactions of Andrographis paniculata and Ibuprofen in the Plasma of Healthy Oryctolagus cuniculus Rabbits
}

\author{
Mutakin $^{1}$, Sandra Megantara ${ }^{1}$, Batari A. Larasati ${ }^{2}$, Yogiyanto $^{2}$, Jutti Levita ${ }^{3}$, Slamet Ibrahim ${ }^{4}$ \\ ${ }^{1}$ Department of Pharmaceutical Analysis and Medicinal Chemistry, \\ Faculty of Pharmacy, Universitas Padjadjaran, Bandung, West Java, Indonesia \\ ${ }^{2}$ Undergraduate Program of Pharmacy, \\ Faculty of Pharmacy, Universitas Padjadjaran, Bandung, West Java, Indonesia \\ ${ }^{3}$ Department of Pharmacology and Clinical Pharmacy, \\ Faculty of Pharmacy, Universitas Padjadjaran, Bandung, West Java, Indonesia \\ ${ }^{4}$ School of Pharmacy, Bandung Institute of Technology, Bandung, West Java, Indonesia
}

\begin{abstract}
An HPLC method was developed and validated for the pharmacokinetic drug-drug interaction between Andrographis paniculata and ibuprofen in the plasma of Oryctolagus cuniculus rabbits after a single oral administration of the mixture. Nine healthy rabbits $(6$ males and 3 females, weight 1.68-2.42 kg) were acclimatized for 7 days and were randomly divided into 3 groups. At day-8th the rabbits were group (1) treated with a single oral administration of ibuprofen (dose of $28 \mathrm{mg} / \mathrm{kg} \mathrm{BW}$ ); group (2) treated with a single oral administration of Andrographis paniculata infusion (7.04 mL/kg BW); group (3) treated with a single oral administration of a mixture of Andrographis paniculata $(7.04 \mathrm{~mL} / \mathrm{kg} \mathrm{BW})$ infusion and ibuprofen (dose of $28 \mathrm{mg} / \mathrm{kg} \mathrm{BW}$ ). Plasma samples were prepared by collecting the blood from the marginal ear vein at $0,30,60,90$, and 120 minutes after the mixture administration, followed by centrifuging it for 30 minutes $3000 \mathrm{rpm}$. Chromatographic separation was performed on a LiChrosorb RP-18 with methanol and double-distilled water (70:30) as the mobile phase, flow rate $1 \mathrm{~mL} /$ minute. UV detection was set at $227 \mathrm{~nm}$. The absorption and distribution of ibuprofen were fast (Tmax $=30 \mathrm{~min}$; $\mathrm{Cmax}=4.02962 \mathrm{mcg} / \mathrm{mL}$ ), however, interestingly this drug could improve the absorption and distribution of andrographolide in Oryctolagus cuniculus rabbits.
\end{abstract}

Keywords: Andrographis paniculata, andrographolide, antiinflammation, ibuprofen, NSAIDs

\section{Introduction}

The bioavailability of a drug is defined as its amount and rate in the systemic circulation. Once entering the blood, the concentration of a drug will denote its total concentration in the circulatory system. ${ }^{1}$
The bioavailability of a drug can be interfered with by another drug when both drugs are administered at the same time due to the occurrence of pharmacokinetic drug-drug interactions (DDIs). Many pharmacokinetic DDIs studies in humans have been reported

Corresponding author: Mutakin. Department of Pharmaceutical Analysis and Medicinal Chemistry, Faculty of Pharmacy, Universitas Padjadjaran, Bandung, West Java, Indonesia. Email: mutakin@unpad.ac.id Received: 8 May 2020. Revised: 23 May 2020. Published: 1 June 2020. 
underlying the mechanisms for DDIs of different degrees. ${ }^{2-6}$

Andrographolide has been reported in possessing anti-inflammatory activity among its other pharmacological activities. ${ }^{7-11} \mathrm{~A}$ previous bioavailability study of sambiloto (Andrographis paniculata) infusion, determined as andrographolide (Figure 1a), reported that this lactone diterpene compound was absorbed and quantified in the plasma of New Zealand male rabbits at $1.5 \mathrm{~h}(\mathrm{Cmax}=0.2136 \mu \mathrm{g} / \mathrm{mL})$ after a single oral administration. ${ }^{12}$ A bioavailability of andrographolide in a mixture of ethanolic extracts of sambiloto and turmeric in rabbits has been reported. In this study, andrographolide was absorbed and distributed in blood within 60-90 minutes $(\mathrm{Cmax}=3.06$ $4.41 \mathrm{ppm}) .{ }^{13}$ However, there is a very limited report of its pharmacokinetic DDIs study with NSAIDs. This work aimed to study the pharmacokinetic DDIs of Andrographis paniculata infusion and ibuprofen (Figure 1b) in the plasma of healthy Oryctolagus cuniculus rabbits.

\section{Methods}

\section{Chemicals and Plants}

Andrographolide 98\% $500 \mathrm{mg}$ CAS 550858-7 for R \& D use (Aldrich) (Figure 1a), ibuprofen pharmaceutical grade (CV Agung Menara Abadi, Bandung) (Figure 1b), chloroform (Merck), double-distilled water for HPLC (PT IPHA), methanol for HPLC (JT Baker), dried sambiloto (Andrographis paniculata) herbs and the fresh plants were obtained from Kebun Percobaan Manoko Lembang. The plants were taxonomically identified at Taxonomy Laboratory, Faculty of Mathematics and Natural Sciences, Universitas Padjadjaran (Letter No. 419/ $\mathrm{HB} / 05 / 2016$ ).

Identification of Ibuprofen and Andrographolide

Each 2-5 mg of ibuprofen and andrographolide was dispersed in 195-198 mg of potassium bromide crystals. The pellets were measured by using the FT-IR instrument (Shimadzu IR Prestige-21) in the range of 1781-1683 cm-1 (Figure 2).

Determination of the Maximum Absorption of Ibuprofen and Andrographolide

Each $10 \mathrm{mg}$ of ibuprofen and andrographolide was dissolved separately in analytical grade ethanol (for ibuprofen) and methanol (for andrographolide) to obtain $25 \mathrm{mcg} / \mathrm{mL}$. The solutions were scanned (Figure 3) in a UV spectrophotometer (Specord 200, Analitik Jena).

\section{Optimization of the HPLC System}

$20 \mathrm{mcg} / \mathrm{mL}$ of andrographolide solution was injected into a $\mathrm{C}-18$ column with a mixture
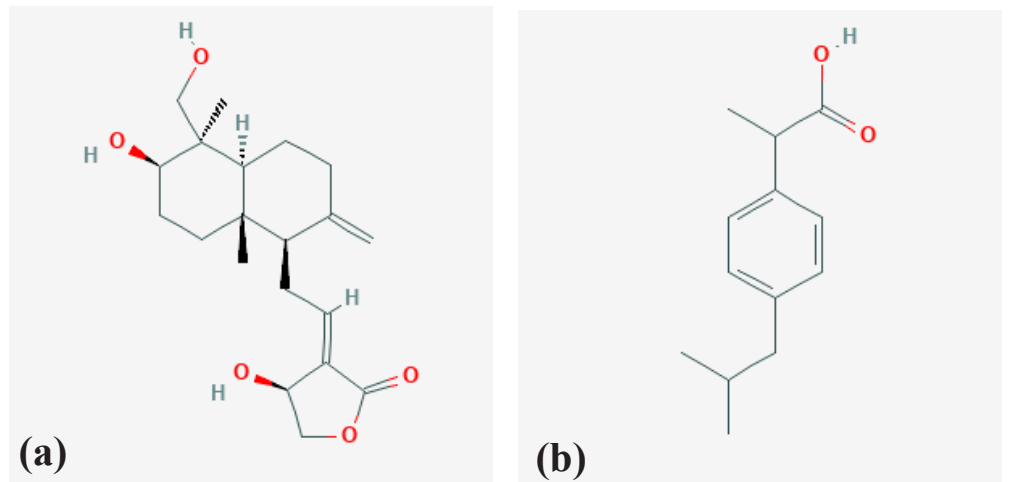

Figure 1. 2D structure of (a) andrographolide and (b) ibuprofen 
of methanol: double distilled water $(55: 45$, $65: 35$, and 70:30) as the mobile phase. The flow rate was $1 \mathrm{~mL} /$ minute and detection was set at $227 \mathrm{~nm}$. Parameters observed were resolution, time of retention, and tailing factor.

Validation of Bioanalytical Method

Validation was performed by following the method proposed by Levita et al., 2013. ${ }^{12}$

\section{Preparation of Andrographis paniculata} Infusion

The preparation of Andrographis paniculata infusion was carried out by following the method proposed by Levita and co-workers. ${ }^{12}$

\section{Animals}

This research has been approved by The Ethics Research Committee of Universitas Padjadjaran (Document No. 1047/UN6/ C1.3.2/KEP/PN/2016). Nine healthy New Zealand rabbits (6 males and 3 females, weight $1.68-2.42 \mathrm{~kg}$ ) were purchased from Peternakan, Budidaya, dan Wirausaha Rajawali Farm. The rabbits were randomly divided into 3 groups and were acclimatized for 7 days. Standard pellet feeds (@75 g/ rabbit) were given twice at 08.00 and 16.00 daily.

The pharmacokinetic DDIs of Andrographis paniculata infusion and ibuprofen in the plasma of healthy Oryctolagus cuniculus rabbits

At day-8th the rabbits were observed for their heart rate (HR), respiration rate, body temperature, and body weight at day-8th (Table 1). At the same day, the rabbits were hematology-analyzed (Table 1) and were treated with: group (1) a single oral administration of ibuprofen (dose of $28 \mathrm{mg} / \mathrm{kg}$ BW); group (2) a single oral administration of Andrographis paniculata infusion $(7.04 \mathrm{~mL} /$ $\mathrm{kg} \mathrm{BW}$ ); group (3) a single oral administration of a mixture of Andrographis paniculata $(7.04 \mathrm{~mL} / \mathrm{kg} \mathrm{BW})$ infusion and ibuprofen (dose of $28 \mathrm{mg} / \mathrm{kg} \mathrm{BW}$ ). Plasma samples were prepared by collecting the blood from the marginal ear vein (Figure 5) at 0, 30, 60, 90, and 120 minutes after the mixture administration, followed by centrifuging it for 30 minutes $3000 \mathrm{rpm}$. Chromatographic separation was performed on a LiChrosorb RP-18 with methanol and double-distilled water $(70: 30)$ as the mobile phase, flow rate 1 $\mathrm{mL} /$ minute. UV detection was set at $227 \mathrm{~nm}$.

\section{Results and Discussion}

Infrared and Ultraviolet Spectrophotometry The ultraviolet spectrum of andrographolide showed one maximum at $227 \mathrm{~nm}$, which is caused by the pi -> pi* transition of two double bonds (C8-C9 and $\mathrm{C} 11-\mathrm{C} 12)$. The peak of ibuprofen occurs at $225 \mathrm{~nm}$ due to the aromatic transition.

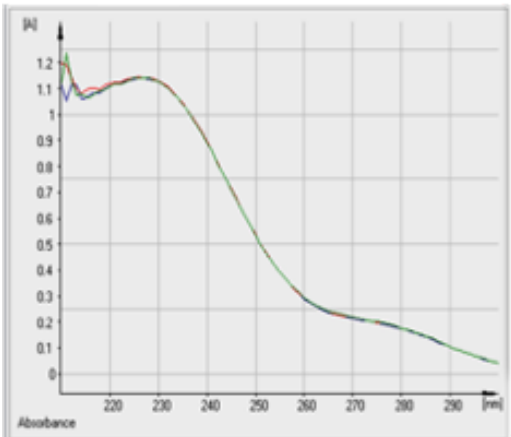

(a)

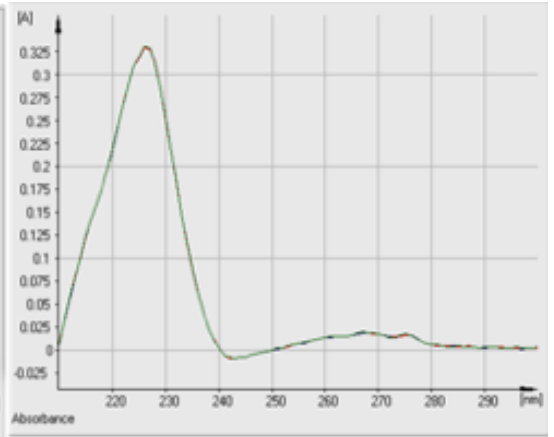

(b)

Figure 2. The UV spectrum of (a) andrographolide and (b) ibuprofen 


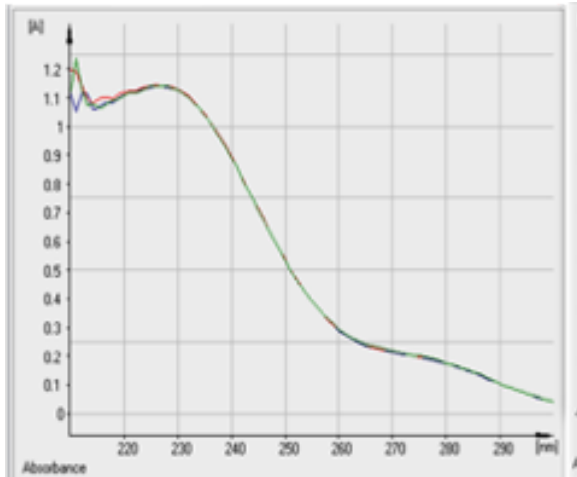

(a)

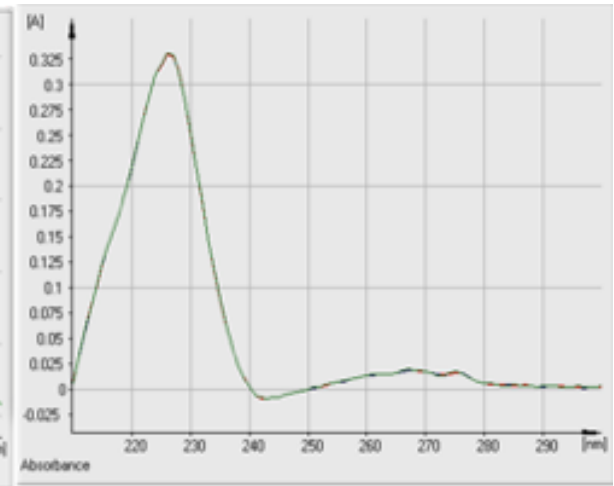

(b)

Figure 3. The infrared spectrum of (a) andrographolide and (b) ibuprofen

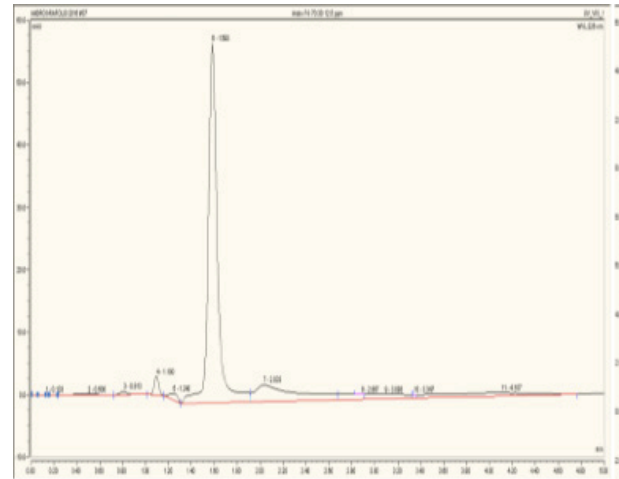

(a)

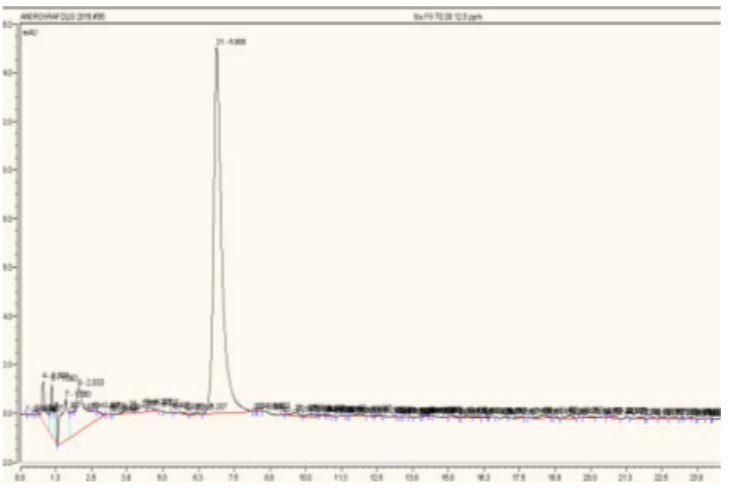

(b)

Figure 4. The HPLC chromatogram of (a) andrographolide (pure compound) and (b) ibuprofen

The IR spectrum of andrographolide (Figure $3 a)$ reveals the presence of O-H $\left(3398 \mathrm{~cm}^{-}\right.$ $\left.{ }^{1}\right)$, alkyls $\left(2969 \mathrm{~cm}^{-1}, 2929 \mathrm{~cm}^{-1}\right.$ and 2847.92 $\left.\mathrm{cm}^{-1}\right)$, carbonyl $(1726 \mathrm{~cm}-1)$, alkene $-\mathrm{C}=\mathrm{C}$ $\left(1674 \mathrm{~cm}^{-1}\right.$ ), while ibuprofen (Figure $3 \mathrm{~b}$ ) shows aromatics $\left(1438.10 \mathrm{~cm}^{-1}\right)$, carbonyl of carboxylic acid $\left(1714.75 \mathrm{~cm}^{-1}\right)$, and overlapped O-H with alkyl $\left(2940.53 \mathrm{~cm}^{-1}\right)$.

\section{Optimization of the HPLC System}

The optimization of the HPLC system indicated that methanol: double distilled water (70:30) is the best condition (resolution 1.39; retention factor 0.94 ; tailing factor 1.14; retention time 1.58 minutes). The chromatogram of andrographolide (Figure 4a) indicates a distinct peak at 1.58 minutes, while ibuprofen elutes at 6.88 minutes.
Validation of Bioanalytical Method

Validation of the bioanalytical method resulted in a good linearity $(\mathrm{y}=0.5349 \mathrm{x}+$ $0.9888 ; \mathrm{R} 2=0.9971), \%$ recovery $93.85-$ $107.53 \%$; RSD $=3.976 \%$; LLOD $=0.11304$ $\mathrm{mcg} / \mathrm{mL}$ and LLOQ $=0.376799 \mathrm{mcg} / \mathrm{mL}$.

The pharmacokinetic DDIs of Andrographis paniculata infusion and ibuprofen in the plasma of healthy Oryctolagus cuniculus rabbits

During 7 days of acclimatization, all rabbits were in healthy condition as proven by their physiological status (Table 1) and biochemical parameters (Table 2).

Rabbits are defined as suffering an abnormal condition when its heart rate exceeds 300 
Table 1. Health condition of the rabbits at day-8th

\begin{tabular}{|c|c|c|c|c|c|c|c|}
\hline \multirow[t]{2}{*}{ Rabbit } & \multirow[t]{2}{*}{ BW (kg) } & \multicolumn{2}{|c|}{$\begin{array}{l}\text { Heart rate } \\
\text { per minute }\end{array}$} & \multicolumn{2}{|c|}{$\begin{array}{l}\text { Respiration rate } \\
\text { per minute }\end{array}$} & \multicolumn{2}{|c|}{$\begin{array}{l}\text { Body temperature } \\
\qquad\left({ }^{\circ} \mathrm{C}\right)\end{array}$} \\
\hline & & Experiment & Reference & Experiment & Reference & Experiment & Reference \\
\hline 1 & 1.80 & 131 & \multirow{9}{*}{$130-300$} & 60 & \multirow{9}{*}{$30-60$} & 37.33 & \multirow{9}{*}{$38-40$} \\
\hline 2 & 2.08 & 124 & & 55 & & 38.44 & \\
\hline 3 & 2.04 & 147 & & 68 & & 38.01 & \\
\hline 4 & 1.96 & 147 & & 58 & & 38.29 & \\
\hline 5 & 1.68 & 122 & & 64 & & 37.76 & \\
\hline 6 & 2.20 & 139 & & 62 & & 38.71 & \\
\hline 7 & 2.40 & 129 & & 65 & & 38.46 & \\
\hline 8 & 2.42 & 134 & & 62 & & 38.41 & \\
\hline 9 & 2.08 & 145 & & 62 & & 38.34 & \\
\hline
\end{tabular}

Reference is cited from River et $\mathrm{al}^{15}$

rate/minute and respiration rate is above $220 /$ minute. ${ }^{15}$

According to Melillo (2007) and Özkan (2012), the normal value of leucocyte and hematocrit ranges $33.10-10.57 \% .^{16,17}$

The blood sampling from the marginal ear vein of the rabbit was carried out as described by Parasuraman et al. (2010) ${ }^{14}$ (Figure 5).

The pharmacokinetic profile of Andrographis paniculata infusion (determined as andrographolide) in the plasma of healthy Oryctolagus cuniculus rabbits compared to those of ibuprofen alone and the mixture of ibuprofen and Andrographis paniculata infusion is presented in Figure 6.

Figure 6 showed that Andrographis paniculata (measured as andrographolide) was quantified in the plasma at 90 minutes (Figure 6: red curve), while ibuprofen was absorbed faster and reached its maximum at 60 minutes (Figure 6: blue curve; $\mathrm{Tmax}=30 \mathrm{~min}$; $\mathrm{Cmax}=$ $4.02962 \mathrm{mcg} / \mathrm{mL}$ ). Interestingly, the absorption of Andrographis paniculata is enhanced by ibuprofen as proven by its occurrence in the rabbit's blood at 60 minutes (Figure 6: green curve). These data confirmed that there is a pharmacokinetic DDIs between Andrographis paniculata (measured as andrographolide) and ibuprofen when these compounds are taken together at the same time.

\section{Conclusion}

A pharmacokinetic DDIs between Andrographis paniculata (measured as andrographolide) and ibuprofen was observed in the plasma of healthy rabbits. Interestingly, our data indicated that the oral administration of ibuprofen together with Andrographis paniculata could improve the absorption and distribution of the latter in Oryctolagus cuniculus rabbits.

\section{Acknowledgement}

This research was funded by the AcademicLeadership Grant of Universitas Padjadjaran of Prof. Dr. Jutti Levita, M.Si., Apt.

\section{References}

1. Kok-Yong S and Lawrence L (2015). Drug Distribution and Drug Elimination, Basic 
Table 2. Health condition of the rabbits at day-8th

\begin{tabular}{|c|c|c|c|c|c|c|c|c|c|}
\hline \multirow[t]{2}{*}{ Parameter } & \multicolumn{9}{|c|}{ Rabbit Code } \\
\hline & R1 & $\mathrm{R} 2$ & R3 & $\mathrm{R} 4$ & R5 & R6 & R7 & $\mathrm{R} 8$ & R9 \\
\hline Leucocyte $\left(10^{\wedge} 3 / \mu 1\right)$ & 10.76 & 9.03 & 11.91 & - & 5.25 & 15.84 & 8.69 & 6.01 & 7.68 \\
\hline Lymphocyte $\left(10^{\wedge} 3 / \mu 1\right)$ & 4.02 & 3.45 & 2.67 & - & 2.36 & 9.13 & 1.11 & 2.83 & 5.31 \\
\hline Monocyte $\left(10^{\wedge} 3 / \mu 1\right)$ & 1.88 & 1.08 & 2.25 & - & 2.09 & 2.64 & 2.27 & 0.59 & 0.78 \\
\hline Granulocyte $\left(10^{\wedge} 3 / \mu 1\right)$ & 4.85 & 4.51 & 6.99 & - & 0.80 & 4.07 & 5.30 & 2.59 & 1.59 \\
\hline Lymphocyte (\%) & 37.40 & 38.20 & 22.40 & - & 45.00 & 57.60 & 12.80 & 47.10 & 69.20 \\
\hline Monocyte (\%) & 17.50 & 12.00 & 18.90 & - & 39.80 & 16.70 & 26.20 & 9.80 & 10.10 \\
\hline Granulocyte (\%) & 45.10 & 49.90 & 58.70 & - & 15.20 & 25.70 & 61.00 & 43.10 & 20.70 \\
\hline Erythrocyte $\left(10^{\wedge} 6 / \mu 1\right)$ & 5.37 & 6.49 & 5.63 & - & 4.96 & 5.51 & 4.32 & 5.35 & 4.73 \\
\hline $\mathrm{Hb}(\mathrm{g} / \mathrm{dl})$ & 11.60 & 14.70 & 13.00 & - & 12.20 & 12.40 & 10.80 & 12.30 & 11.40 \\
\hline Hematocrit (\%) & 28.92 & 38.00 & 32.32 & - & 31.62 & 33.23 & 27.27 & 31.80 & 29.94 \\
\hline $\begin{array}{l}\text { Mean corpuscular vol- } \\
\text { ume (fl) }\end{array}$ & 54 & 599 & 57 & - & 64 & 60 & 63 & 59 & 63 \\
\hline $\begin{array}{l}\text { Mean corpuscular he- } \\
\text { moglobin (pg) }\end{array}$ & 21.6 & 22.6 & 23.2 & - & 24.7 & 22.5 & 25.1 & 22.9 & 24.2 \\
\hline $\begin{array}{l}\text { Mean corpuscular he- } \\
\text { moglobin concentration } \\
(\mathrm{g} / \mathrm{dl})\end{array}$ & 40.2 & 38.6 & 40.4 & - & 38.7 & 37.3 & 39.8 & 38.6 & 38.2 \\
\hline $\begin{array}{l}\text { Red cell distribution } \\
\text { width }(\%)\end{array}$ & 18.3 & 16.6 & 16.1 & - & 15.5 & 16.4 & 18.4 & 16.4 & 16.2 \\
\hline Platelet $\left(10^{\wedge} 3 / \mu 1\right)$ & 254 & 417 & 151 & - & 105 & 342 & 232 & 195 & 223 \\
\hline Plateletcrit (\%) & 0.14 & 0.13 & 0.04 & - & 0.03 & 0.17 & 0.12 & 0.03 & 0.12 \\
\hline $\begin{array}{l}\text { Mean platelet volume } \\
\text { (fl) }\end{array}$ & 5.6 & 3.2 & 2.7 & - & 3.2 & 5 & 5.3 & 1.6 & 5.2 \\
\hline $\begin{array}{l}\text { Platelet distribution } \\
\text { width \% }\end{array}$ & 33.80 & 33 & 30.2 & - & 29.5 & 33.8 & 33.8 & 28.5 & 32.3 \\
\hline
\end{tabular}

Pharmacokinetic Concepts and Some Clinical Applications, Tarek A Ahmed, IntechOpen, DOI: 10.5772/59929. Available from: https://www.intechopen. com/books/basic-pharmacokineticconcepts-and-some-clinical-applications/ drug-distribution-and-drug-elimination

2. Li W, Zeng $\mathrm{S}, \mathrm{Yu}$ L-S, Zhou Q. Pharmacokinetic Drug Interaction Profile of Omeprazole With Adverse Consequences and Clinical Risk
Management. Therapeutics and Clinical Risk Management. 2013; 9: 259-271. doi: 10.2147/TCRM.S43151

3. Zhou Y-T, Yu L-S, Zeng S, Huang Y-W, $\mathrm{Xu}$ H-M, Zhou Q. Pharmacokinetic Drug-Drug Interactions Between 1,4-dihydropyridine Calcium Channel Blockers and Statins: Factors Determining Interaction Strength and Relevant Clinical Risk Management. Therapeutics and Clinical Risk Management. 2014; 10: 17- 


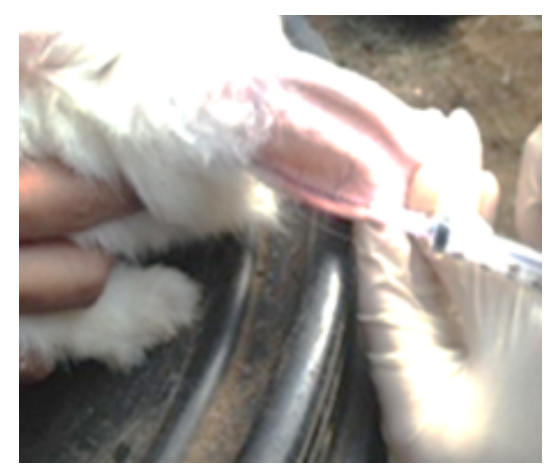

Figure 5. Blood collection from the marginal ear vein of the rabbit

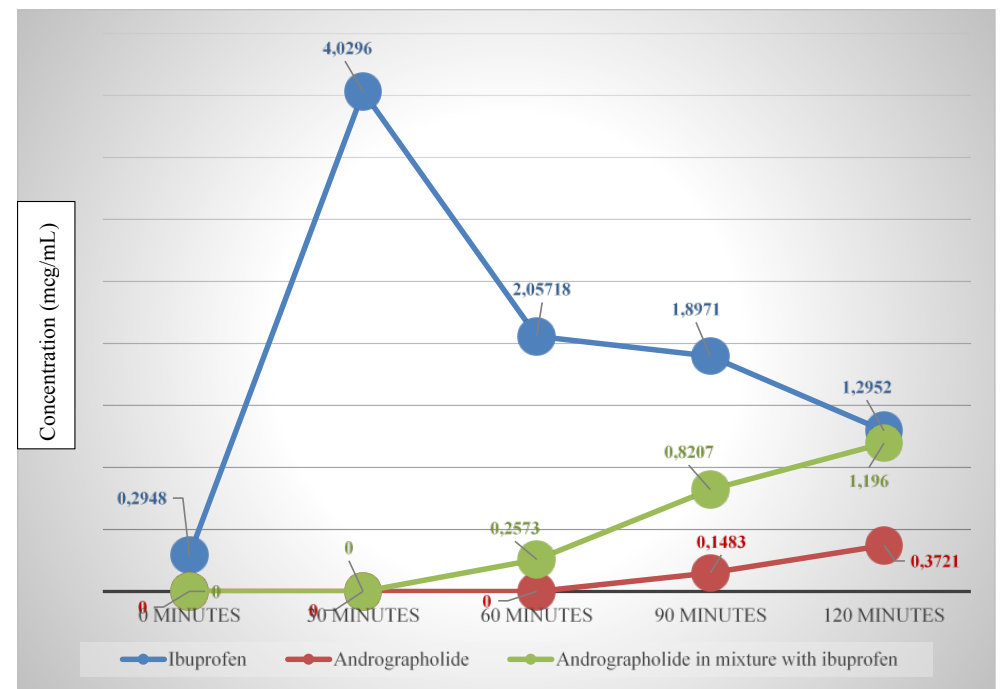

Figure 6. Pharmacokinetic profile of ibuprofen (blue; Tmax $=30 \mathrm{~min}$; Cmax $=4.02962 \mathrm{mcg} / \mathrm{mL}$ ), andrographolide (red), and the mixture of Andrographis paniculata and ibuprofen (green) in Oryctolagus cuniculus rabbit's plasma

\section{DOI: $10.2147 /$ TCRM.S55512}

4. Wang Y-C, Hsieh T-C, Chou C-L, Wu J-L, Fang T-C. Risks of Adverse Events Following Coprescription of Statins and Calcium Channel Blockers: A Nationwide Population-Based Study. Medicine (Baltimore). 2016; 95(2): e2487. DOI: 10.1097/MD.0000000000002487

5. Banakh I, Haji K, Kung R, Gupta S, Tiruvoipati R. Severe Rhabdomyolysis Due to Presumed Drug Interactions Between Atorvastatin With Amlodipine and Ticagrelor. Case Reports in Critical Care. 2017; 3801819. DOI:

\section{$10.1155 / 2017 / 3801819$}

6. 6. Moon SJ, Jeon J-Y, Jang K, Yu K-S, Lim Y, Kim M-G, Pharmacokinetic Interactions Between Telmisartan/ Amlodipine and Rosuvastatin After Multiple Oral Administrations in Healthy Korean Male Subjects. Drug Design, Development, and Therapy. 2019; 13: 2533-2542. DOI: 10.2147/DDDT. S210364. eCollection 2019

7. Shen YC, Chen CF, Chiou WF. Andrographolide prevents oxygen radical production by human neutrophils: possible mechanism(s) involved in its 
anti-inflammatory effect. British Journal of Pharmacology. 2002; 135(2): 399-406

8. Abu-Ghefreh AA, Canatan H, Ezeamuzie CI. In Vitro and in Vivo Anti-Inflammatory Effects of Andrographolide. International Immunopharmacology. 2009; 9(3): 313318. DOI: 10.1016/j.intimp.2008.12.002

9. Levita J, Nawawi A, Mutalib A, Ibrahim S. Andrographolide Inhibits COX-2 Expression in Human Fibroblast Cells Due to Its Interaction with Arginine and Histidine in Cyclooxygenase Site. Journal of Applied Sciences. 2010; 10(14): 14811484.

10. Shen T, Yang WS, Yi Y-S, Sung G-H, Rhee $\mathrm{MH}$, Poo H, Kim M-Y, Kim K-W, Kim JH, Cho JY. AP-1/IRF-3 Targeted Anti-Inflammatory Activity of Andrographolide Isolated from Andrographis paniculata. Evidence-Based Complementary and Alternative Medicine. 2013: Article ID 210736. DOI: https://doi. org/10.1155/2013/210736

11. Sumiwi SA, Halimah E, Saptarini NM, Levita J, Nawawi A, Mutalib A, Ibrahim S. Inhibitory Activity of Andrographolide and Andrograpanin on the Rate of PGH2 Formation. Pharmacology and Clinical Pharmacy Research. 2016; 1(3): 79-83. DOI: $10.15416 /$ pcpr.v1i3.15246

12. Levita J, Himawati H, Lukman RV, Afdila M, Holik HA, Saptarini NM, Hasanah AN, Nawawi A, Mutalib A, Ibrahim S. Bioavailability Study of Sambiloto(Andrographispaniculata)Herbs Infusion in Rabbit. Indonesian Journal of Pharmacy. 2013; 25(3): 138-144. DOI: 10.14499/indonesianjpharm25iss3pp138

13. Budipramana K. 2009. Penentuan Parameter Ketersediaan Hayati Andrografolida dan Kurkumin dari Campuran Ekstrak Herba Sambiloto (Andrographis paniculata Nees.) dari Rimpang Kunyit (Curcuma domestica Val.) dalam Serum kelinci Menggunakan
HPLC. Fakultas Farmasi Universitas Airlangga Departemen Farmakognosi dan Fitokimia. Abstrak.

14. Parasuraman S, Raveendran R, Kesavan R. Blood sample collection in small laboratory animals. Journal of Pharmacology and Pharmacotherapeutics. 2010; 1(2): 87-93.

15. River C. 2011. Handbook of Clinical Signs in Rodents and Rabbits. Charles River Laboratories International.

16. Melillo A. Rabbit Clinical Pathology. Journal of Exotic Pet Medicine. 2007; 16: 135-145.

17. Özkan C, Kaya A, Akgül Y. Normal Values of Haematological and Some Biochemical Parameters in Serum and Urine of New Zealand White Rabbits. World Rabbit Science. 2012; 253 - 259. 